\title{
Co-creating Social Change through Citizen Science: Systematic Literature Analysis
}

\author{
MONIKA MAČIULIENĖ, EGLE் BUTKEVIČIENĖ, EGLE் VAIDELYTE், \\ BÁLINT BALÁZS \\ Kaunas University of Technology, 73 K. Donelaičio Street, Kaunas, Lithuania \\ Email: monika.maciuliene@ktu.It; egle.butkeviciene@ktu.lt; egle.vaidelyte@ktu.lt; balint.balazs@ktu.It
}

\begin{abstract}
Citizen science encompasses partnerships between professional scientists and society, opening opportunities for more active citizen engagement in co-creation of social change. Members of the scientific community and citizens are starting to experiment with digital and offline resources to collaborate with each other to solve societal problems. This article aims to discuss the possible role of citizen science in co-creating social change in society or local community settings. The article is based on systematic literature analysis. The findings* show that co-created research might have a particularly strong impact on the wealth of society and wider outcomes in the local or regional settings. However, such cases are not very common yet. Although academic research on co-creative approaches to citizen science and stakeholder engagement is growing at a steady rate, it remains a relatively emergent domain.
\end{abstract}

Keywords: citizen science, social change, co-creation, literature review

\section{INTRODUCTION}

In the most basic sense, science is a way of knowing about the world. It enables different actors to not only engage in the construction of new knowledge but also use acquired information to achieve desired outcomes. Research from a variety of perspectives (e.g. open innovation, open government, crowdsourcing, collective intelligence) argues that innovation and new knowledge no longer originates in a single organization (e.g. university, research centre) but rather is distributed in a network of multiple stakeholders. One of the key practices that opens up scientific processes and makes use of networked knowledge is the practice of citizen science (CS).

Most CS projects occur within problem-focused natural science (Crain et al. 2014) and are not firmly established in social sciences (Heiss, Matthes 2017). The survey conducted by Hecker et al. (2018) revealed that $80 \%$ of CS projects take place in life and natural sciences and

* This paper has been developed under the research project 'Citizen Science as an Innovative Form of Citizen Participation for Welfare Society Development' (CS4Welfare), funded by the Research Council of Lithuania (Agreement No. S-GEV-20-6). 
only $11 \%$ dig into the questions in social sciences and humanities. Social science research is yet to benefit from public engagement since the contributions of citizens have become more feasible because of the Internet-based technologies. This asymmetry exists 'despite the huge potential of collecting innovative, large-scale data, which may solve important scientific and social questions' such as 'health issues, the effectiveness of social institutions and social equity' (Heiss, Matthes 2017: 23).

What is lacking is a thorough assessment of the role of CS in co-creating social change. The theoretical, conceptual and empirical contributions still have areas of opportunities to explore. Thus, this article is dedicated to contribute to structuring the understanding of how co-creation is used in CS by discussing the main research question of what are the aims, approach, the context and stakeholders of co-creation in CS projects.

The aim of this article: To address these above mentioned shortcomings in current research and practice of CS, we set out an aim to explore the dynamics between co-creation and CS, highlighting the potential of CS to solve social problems and move towards welfare society.

Methods used: A systematic review and analysis of literature allowed us to identify and structure the aims of co-creation through CS, context and different types of stakeholder engagement.

\section{CITIZEN SCIENCE AND THE ROLE OF CITIZENS IN CO-CREATING SOCIAL CHANGE}

Current societal challenges demand new ways of thinking, creativity and knowledge including tacit knowledge, and specifically local knowledge. Local knowledge involves on-the-ground knowledge of communities, statistical data tracking trends in a community and tapping into this is essential for implementing social change in a meaningful way. In addition, Nowotny et al. (2001: 2) suggest that science currently is much more uncertain: 'its composition more heterogeneous, its values more contested, its methods more diverse and its boundaries more ragged'. Social phenomena are much more nonlinear and unpredictable (Rushmer et al. 2019).

CS encompasses partnerships between professional scientists and members of the public in authentic scientific research (Tiago 2017). In the context of welfare society, CS provides a mechanism for citizens and local communities to build social welfare. Expected outcomes of CS projects include increased knowledge in the field of study by members of the society (Jordan et al. 2011), participatory innovations (Hecker et al. 2018), promotion of positive attitudes towards nature (Evans et al. 2005), boosted science literacy (Crall et al. 2012) and responsive education (Bonney et al. 2016). Because of such ambitious intentions, CS is highlighted on the European Union agenda on science policy making as a mechanism fostering the public engagement into scientific processes, research and innovation.

Close relations between the citizens and scientific community might not only allow access to large scale and 'hidden' data but also tie research questions more closely to real existing social problems. The members of the public (i.e. citizens, educators, funders, civil servants, industry) are capable of finding ways to make science useful for themselves, their communities, working environments and the society. Stakeholder engagement democratises science and increases the responsibility of researchers towards society (Purdam 2014).

Academic literature is full of evidence suggesting that civic activity is positively correlated with social and economic welfare indicators (e.g. Lewicka 2008). If we focus on CS specifically, several studies have noted the potential of CS to stimulate broader civic participation 
and to achieve broader individual, social and community-level outcomes (e.g. Ottinger 2016). The next section will discuss the measures and dimensions of CS when applied to solving social problems and promote social change.

\section{WHAT CONSTITUTES CO-CREATION: LEVELS OF ENGAGEMENT IN CITIZEN SCIENCE}

The concept of co-creation originated in the business world where it has been argued that value can only be created through cooperation between businesses and users (Prahalad, Ramaswamy 2004). Central to such thinking is the engagement of external and internal stakeholders through platforms fostering engagement and environments of interaction. Co-creation entails connections and collaboration in generation of the added value for all involved actors (Lönn, Uppström 2015). Information and communication technologies play a vital role in this process since they can be used to remove institutional and geographical barriers linked with information flows. In the science world, co-creation focuses on new knowledge developed together with and not for members of the public. This has been reflected in the academic literature 'with a paradigm shift from the deficit model - in which the general public is defined negatively due to its lack of knowledge - to the participative model - in which the general public is invited to form part of the scientific endeavour' (López-Pérez, Olvera Lobo 2018: 1).

Not all stakeholder participation is the same. Scholars have taken different approaches to stakeholder engagement in the CS-based research process. For example, King et al. (2016) define 3 broad categories of CS: by the people, for the people and with the people. The third type represents the most contributory and collaborative of the approaches, where community members help frame the research questions, collect data and articulate findings. Similarly, Bonney et al. (2009) identified similar modes of cooperation: contributive, collaborative and co-created. At the highest level of engagement, the collaboration entails the characteristics of co-creation and social innovation. Cooper and Lewenstein (2016) classify CS into 2 broad strands: (1) democratic CS focusing on the responsibility of science to society and (2) participatory CS focusing on individual contributions to the scientific enterprise. The breadth of engagement methods reveals important changes in the relationship between science and society. The knowledge is no longer generated in scientific institutions exclusively but in transdisciplinary collaborations. After analysis of different engagement models, a conceptual continuum of stakeholder engagement in the research process was developed (see the Figure).

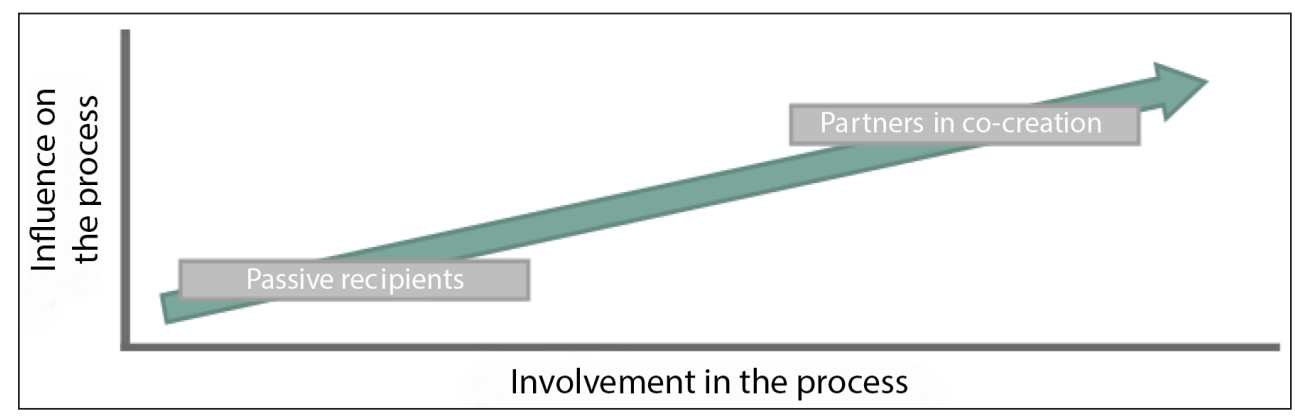

Figure. Conceptual continuum of stakeholder engagement in the research process (developed by the authors, 2021) 
On the left, there are more traditional relationships between the scientists and stakeholders where the latter are treated as passive participants. Such engagement methods are based on the concept of knowledge translation which assumes that research knowledge is created by scientists and research institutions and then is processed to be more accessible to non-academics (Rushmer et al. 2019). The involvement of citizens is minimal and they are passive recipients of scientific knowledge. Going to the right, engagement of stakeholders increases, as they move towards becoming active research partners. Opening up of the processes promotes collective knowledge and challenges traditional power dynamics - there are many actors, many experts and an evolving collaboration. This means that the power is shared among partners in all parts of the research process - defining research questions, collecting and analysing data, drawing conclusions. In most cases, the stakeholders and scientists are jointly involved in the process because they share the same concern - the wellbeing of the community, environment or other wide-ranging issues. According to Greenhalgh et al. (2016), key success factors in co-created research include systems perspective, framing of research as a creative enterprise and an emphasis on process. Co-creative approach means that each stakeholder (scientists included) contributes with resources (e.g. scientific models and methods), knowledge (e.g. local knowledge, practical experience) and collaborative actions in order to find solutions to mutual challenges.

However, citizens' contributions in most CS projects remain of low-complexity and with limited decision rights (Suess-Reyes et al. 2020). The study by Heinich (2017) proves this notion and shows that in the sample of 1,691 CS projects (listed in various academic and practice-based directories), approximately $99 \%$ projects are contributory in nature. The low number of activities aimed at higher levels of knowledge creation might have several culprits. Research projects including a diverse set of stakeholders are often disrupted by asymmetric power structures, unequal partnerships (differences in socio-economic status, knowledge, value, etc.), inherent knowledge barriers, divergent interests, multiplicity of roles and pragmatics of immersion (Wang et al. 2016). Also, research institutions face difficulties in showcasing the added value of citizen engagement projects when addressing complex social problems (Northmore, Hart 2011). Higher levels of knowledge creation based on collective intelligence or participatory actions, hence, are rarely discussed. The research discussed in the following sections is set out to fill in this gap.

\section{METHODOLOGY}

Aiming to understand the trends of co-creation use in CS projects, we used systematic literature analysis. A keyword search was conducted on the Web of Science Core Collection using the keywords 'co-creation + citizen science. The search resulted in 48 documents, including 34 research articles, 7 proceedings papers, 6 reviews, and 2 other materials (see Table 1).

\section{Table 1. Documents for systematic literature analysis}

\begin{tabular}{ccccc}
\hline \multicolumn{5}{c}{ Documents found } \\
\hline Total & Articles & Proceedings papers & Reviews & Materials \\
\hline 48 & 34 & 7 & 6 & 2 \\
\hline 22 & 15 & Documents selected & & 0 \\
\hline
\end{tabular}


A selection of publications for further analysis was performed by reviewing the titles, keywords and abstracts. Overall, the following criteria were used to select the documents for further analysis: 1) the publication has both keywords ('co-creation + citizen science') either in the title, keywords or abstract; 2) the publication is listed on the Web of Science database; 3) the publication is in English. Using these criteria, 22 publications were selected for content analysis, including 15 research articles, 2 proceedings papers and 5 reviews. The publications that represent our sample are marked with an asterisk $\left(^{*}\right)$ in the list of references.

This article is focussed on the analysis of documents published during the period of 2015-2020: 2015 (1), 2016 (0), 2017 (3), 2018 (5), 2019 (8) and 2020 (5). The biggest number of publications represent a year of 2019.

The analysis included 4 main criteria: (1) the approach, (2) the aim, (3) the context, and (4) the stakeholders of co-creation in CS projects.

Limitations of the study. Due to limitations of the sample size, analysis of publications does not include quantitative aspects, and entirely is focused on qualitative analysis, mainly a traditional narrative review, presented in the next section.

\section{RESULTS AND DISCUSSION}

The analysis of empirical results has been focussed on several aspects: (1) the approach to co-creation of welfare in CS projects; (2) the aims of co-creation in CS; (3) the context of co-creation in CS projects; (4) the stakeholders involved in the process of co-creation in CS projects.

The approach to co-creation of social change in CS projects. As our research has shown, the co-creation of value can be understood vastly differently by academics (see Table 2 below). When considering the general features of analysed studies, hitherto, there are two main streams:

- Co-creation of social change as an output. While some authors refer to co-creation as an output and generation of higher level knowledge such as discovery of community priorities (Asingizwe et al. 2019; Kim et al. 2020), developing solutions that are culturally acceptable (Kim et al. 2020), provoking reflection (Rogers, Rock 2017) and changes in community knowledge, attitudes and behaviours (Pecl et al. 2019).

- Co-creation of social change as a process. The second group looks at co-creation as a process and focuses on the changing power dynamics between different stakeholders. For example, Torras-Gómez, Guo and Ramis (2019) focuses on inclusion of all voices in social transformations through CS. Cieslik et al. (2018) focuses on increased levels of connectivity in the process of knowledge creation and connective action. Onencan, Meesters and Van de Walle (2018) focuses on crowdsourced approach in community decision-making.

Table 2. The approach to co-creation of social change in CS projects

\begin{tabular}{l|l}
\hline \multicolumn{1}{c|}{ Co-creation of social change as an output } & \multicolumn{1}{c}{ Co-creation of social change as a process } \\
\hline - Identification/discovery of community priorities & $\begin{array}{l}\text { - Changing power dynamics between different } \\
\text { through CS projects }\end{array}$ \\
$\begin{array}{l}\text { Developing solutions for problem solving } \\
\text { - Changes in community knowledge, attitudes and }\end{array}$ & $\begin{array}{l}\text { - Crowdsourcing in community decision-making } \\
\text { behaviours }\end{array}$ \\
\hline
\end{tabular}

Source: developed by the authors (2021). 
The aims of co-creation in CS. All articles deliberate CS projects aiming to reach several/multiple goals. For example, Asingizwe et al. (2019) focuses on community surveillance but also discusses how CS activities can raise awareness on health-related issues. Complex goals are also identified in research by Mahajan et al. (2020), Asingizwe et al. (2019) and Pecl et al. (2019). Such divergent views lead to a conclusion that value co-creation design varies from situation to situation and there are no pre-set rules or guaranteed strategies for the process.

The context of co-creation in CS projects. CS engages non-professionals in authentic scientific research, ranging from healthcare to ecology. This sample is no exception. Publication content analysis was conducted to identify the context and problem areas where co-creative methods were applied. We were able to identify six: air pollution (Mahajan et al. 2020), museum exhibitions (Rogers, Rock 2017), climate action (Groulx et al. 2019), biodiversity (Schröter et al. 2017; Pescott et al. 2019), disaster risk reduction (Onencan et al. 2018) and health research (Kim et al. 2020; Asingizwe et al. 2019). Despite the differences in the context, the members of the public are the foundation of CS projects.

Another pattern noticed in the literature review was that the existing resources on co-creation rely to a great extent on single case studies. In order to understand the complexities of knowledge co-creation through CS new research approaches are required. Comparison between initiatives from different countries and multiple case studies can pinpoint to what extent contextual, national and regional specifics are influential. Some studies move towards this direction. Pant (2019) develops a conceptual matrix model of university, government, industry and civil society collaboration. Macq, Tancoigne and Strasse (2020) reviews EU policies related to citizen engagement into science and the role and value of public participation in science, technology and innovation. Craglia and Shanley (2015) discusses technology-led developments and opportunities they have created for the increased participation of the public in generating scientific information. Others evaluate recent trends, risks and opportunities of using CS in co-creation of value. For example, Schröter et al. (2017) looks into research focused on utilization of CS in ecosystem service studies. Njue et al. (2019) provides a comprehensive review on CS within a context of hydrology. Knapp et al. (2019) offers insights into the interaction between science and practice. Finally, Fulgenzi et al. (2020) explores the rationale for knowledge co-production.

The stakeholders involved in the process of co-creation in CS projects. Co-creation of knowledge requires academics to work alongside other stakeholders. Hence, we also looked into the stakeholders involved in co-creative activities. In most cases, the focus was on citizens (e.g. Mahajan et al. 2020; Rogers, Rock 2017; Groulx et al. 2019) and their individual experience in CS processes. Others (e.g. Kim et al. 2020; Onencan et al. 2018; Pecl et al. 2019) centred their focus on communities. For example, Onencan et al. (2018) describes GIS-based CS activities allowing the community to decide whether to avoid, mitigate, transfer or accept different risks related to mining. Other stakeholder groups were mentioned less frequently - public institutions like museums (Rogers, Rock 2017), governmental bodies (Onencan et al. 2018) and regional organizations (Pecl et al. 2019). This points to a clear need to increase the participation and awareness of all stakeholders. Strategies and methods for engaging different stakeholders more deeply in co-creation are needed to address social issues. Involvement of stakeholder groups enables ideas for new solutions to be derived from diverse and unexpected sources. Working in partnership with diverse stakeholder groups, drawing on and developing their assets and capabilities help support society's resilience and capacity to act. 


\section{IMPLICATIONS FOR THEORY AND PRACTICE}

The collection of articles that tied together co-creation and CS is not large. This may be because different researchers use different terminology to describe the same processes. CS is not the only term used to describe engagement of stakeholders in the scientific process. Other research avenues include community science (Wandersman 2003), issue-driven research (Robinson, 2008), participatory research (Häberli, Grossenbacher-Mansuy 1998; Defila, Di Giulio 1999) and transdisciplinary collaboration (Pohl, Hirsch-Hadorn 2007). These concepts differ in nature, but research surrounding them could be useful in developing CS practice further. For example, community science is led by the community (Bonney et al. 2016). Hence, engagement practices analysed in literature on community science could be used by practitioners in CS. The variety of approaches shows that there are ways to design scientific processes with citizens, communities and stakeholders taking an active role. Communities know their welfare priorities best. However, lack of one central theoretical foundation makes the field of CS fragmented. Thus, this study is contributing to a clearer understanding of the relation between CS and co-creation.

\section{CONCLUSIONS}

There is a huge potential for CS to be a force in co-creation of social change. It is hence important that more and more research would document the methods of engagement and management in CS projects focused towards social change. Knowledge creation through CS activities enables solution oriented research through interdisciplinarity (involving experts from different research domains) and transdisciplinarity (involving practitioners from governments, industries, non-profit organizations and civil members). However, CS is not a panacea for effecting change in science and the society.

Although academic research on co-creative approaches to CS and stakeholder engagement is growing at a steady rate, it remains a relatively emergent domain. As the systematic literature has shown, the co-creation of value can be understood in a variety of ways by different researchers but two main streams are prevalent: co-creation of social change as an output and as a process. The aims of co-creation of CS is also mostly undefined and seeks to address complex goals at once. However, one element unites the CS projects - despite the context, members of the public are the foundation of CS projects. However, the citizen engagement strategies improving participation and awareness still need more research attention.

Additional work is needed to formulate measures and indicators of successful co-creation initiatives in CS. Co-created research might have a particularly strong impact on the wealth of society and wider outcomes in the local or regional settings. However, a lot more research is needed to pinpoint the conditions that allow for exchange of knowledge between scientists and stakeholders. Toward this end, we need more CS projects employing co-creative techniques in order to gain empirical facts.

\section{ACKNOWLEDGEMENTS}

This paper has been developed under the research project 'Citizen Science as an Innovative Form of Citizen Participation for Welfare Society Development' (CS4Welfare), funded by the Research Council of Lithuania (Agreement No. S-GEV-20-6). 


\section{References}

1. Asingizwe, D.; Milumbu Murindahabi, M.; Koenraadt, C. J.; Poortvliet, P. M.; Van Vliet, A. J.; Ingabire, C. M.; Leeuwis, C. 2019. 'Co-designing a Citizen Science Program for Malaria Control in Rwanda', Sustainability 11(24): 7012.

2. Bonney, R.; Ballard, H.; Jordan, R.; McCallie, E.; Phillips, T.; Shirk, J.; Wilderman, C. C. 2009. Public Participation in Scientific Research: Defining the Field and Assessing Its Potential for Informal Science Education. A CAISE Inquiry Group Report. Washington, D. C.: Center for Advancement of Informal Science Education (CAISE).

3. Bonney, R.; Cooper, C. B.; Dickinson, J.; Kelling, S.; Phillips, T.; Rosenberg, K. V.; Shirk, J. 2009. 'Citizen Science: A Developing Tool for Expanding Science Knowledge and Scientific Literacy', BioScience 59(11): 977-984.

4. Bonney, R.; Cooper, C. B.; Ballard, H. 2016. 'The Theory and Practice of Citizen Science: Launching a New Journal', Citizen Science: Theory and Practice 1: 1.

5. Cieslik, K. J.; Leeuwis, C.; Dewulf, A. R. P. J.; Lie, R.; Werners, S. E.; Van Wessel, M.; Struik, P. C. 2018. 'Addressing Socio-ecological Development Challenges in the Digital Age: Exploring the Potential of Environmental Virtual Observatories for Connective Action (EVOCA)', NJAS-Wageningen Journal of Life Sciences 86: 2-11.

6. Cooper, C. B.; Lewenstein, B. V. 2016. 'Two Meanings of Citizen Science', in The Rightful Place of Science: Citizen Science. Tempe, AZ: Consortium for Science, Policy \& Outcomes, 51-62.

7. Craglia, M.; Shanley, L. 2015. 'Data Democracy - Increased Supply of Geospatial Information and Expanded Participatory Processes in the Production of Data', International Journal of Digital Earth 8(9): 679-693.

8. Crall, A. W.; Jordan, R.; Holfelder, K.; Newman, G. J.; Graham, J.; Waller, D. 2012. 'The Impacts of an Invasive Species Citizen Science Training Program on Participant Attitudes, Behavior and Science Literacy', Public Understanding of Science. Available at: https://doi.org/10.1177/09636625114348941-20

9. Esping-Andersen, G. 1990. The Three Worlds of Welfare Capitalism. Cambridge: Polity Press.

10. Evans, C.; Abrams, E.; Reitsma, R.; Roux, K.; Salmonsen, L.; Marra, P. 2005. 'The Neighborhood Nestwatch Program: Participant Outcomes of a Citizen-science Ecological Research Project,' Conservation Biology 19: 589-94.

11. Fulgenzi, A.; Brouwer, S.; Baker, K.; Frijns, J. 2020. 'Communities of Practice at the Center of Circular Water Solutions', WIREs Water. Available at: https://doi.org/10.1002/wat2.1450

12. Greenhalgh, T.; Raftery, J.; Hanney, S.; Glover, M. 2016. 'Research Impact: A Narrative Review', $B M C$ Medicine 14(1): 78.

13. Groulx, M.; Fishback, L.; Winegardner, A. 2019. 'Citizen Science and the Public Nature of Climate Action', Polar Geography 42(3): 176-195.

14. Hart, A.; Northmore, S. 2011. 'Auditing and Evaluating University-Community Engagement: Lessons from a UK Case Study', Higher Education Quarterly 65(1): 34-58.

15. Hecker, S.; Bonney, R.; Haklay, M.; Hölker, F.; Hofer, H.; Goebel, C.; Gold, M. et al. 2018. 'Innovation in Citizen Science - Perspectives on Science-Policy Advances', Citizen Science: Theory and Practice 3(1). Available at: https://doi. org/10. 5334/cstp. 114

16. Heinich, N. 2017. Le paradigme de l'art contemporain. Structures d’une révolution artistique. Gallimard.

17. Heiss, R.; Matthes, J. 2017. 'Citizen Science in the Social Sciences: A Call for More Evidence', Gaia 26(1): 22-26. Available at: https://doi.org/10.14512/gaia.26.1.7

18. Jordan, R.; Crall, A.; Gray, S.; Phillips, T.; Mellor, D. 2015. 'Citizen Science as a Distinct Field of Inquiry', BioScience 65(2): 208-211. Available at: https://doi.org/10. 1093/biosci/biu217

19. Kim, S.; Robson, C.; Zimmerman, T.; Pierce, J.; Haber, E. M. 2011. 'Creek Watch: Pairing Usefulness and Usability for Successful Citizen Science', in Proceedings of the SIGCHI Conference on Human Factors in Computing Systems, 2125-2134.

20. Kim, K. K.; Ngo, V.; Gilkison, G.; Hillman, L.; Sowerwine, J.; Karuk Youth Leaders. 2020. 'Native American Youth Citizen Scientists Uncovering Community Health and Food Security Priorities', Health Promotion Practice 21(1): 80-90.

21. Knapp, C. N.; Reid, R. S.; Fernández-Giménez, M. E.; Klein, J. A.; Galvin, K. A. 2019. 'Placing Transdisciplinarity in Context: A Review of Approaches to Connect Scholars, Society and Action', Sustainability 11(18): 4899. 
22. Lewicka, M. 2008. 'Place Attachment, Place Identity, and Place Memory: Restoring the Forgotten City Past', Journal of Environmental Psychology 28(3): 209-231.

23. Lönn, C.-M.; Uppström, E. 2015. 'Core Aspects for Value Co-creation in Public Sector', in Proceedings of 21st Americas Conference on Information Systems (AMCIS 2015). Vol. 2. Association for Information Systems (AIS), 1422-1433.

24. López-Pérez, L.; Olvera Lobo, M. D. 2018. 'Public Engagement in Science via Web 2.0 Technologies. Evaluation Criteria Validated Using the Delphi Method', Journal of Science Communication 17(02): A08. Available at: https://doi.org/10.22323/2.17020208

25. Macq, H.; Tancoigne, É., Strasser, B. J. 2020. 'From Deliberation to Production: Public Participation in Science and Technology Policies of the European Commission (1998-2019)', Minerva 58: 489-512.

26. Mahajan, S.; Kumar, P.; Pinto, J. A.; Riccetti, A.; Schaaf, K.; Camprodon, G.; Forino, G. 2020. 'A Citizen Science Approach for Enhancing Public Understanding of Air Pollution', Sustainable Cities and Society 52: 101800.

27. Njue, N.; Kroese, J. S.; Gräf, J.; Jacobs, S. R.; Weeser, B.; Breuer, L.; Rufino, M. C. 2019. 'Citizen Science in Hydrological Monitoring and Ecosystem Services Management: State of the Art and Future Prospects', Science of the Total Environment 693: 133531.

28. Nowotny, H.; Scott, P.; Gibbons, M. 2001. Re-thinking Science: Knowledge and the Public in an Age of Uncertainty. Cambridge, United Kingdom: Polity Press.

29. Onencan, A. M.; Meesters, K.; Van de Walle, B. 2018. 'Methodology for Participatory GIS Risk Mapping and Citizen Science for Solotvyno Salt Mines', Remote Sensing 10(11): 1828.

30. Ottinger, G. 2016. 'Social Movement-based Citizen Science', in The Rightful Place of Science: Citizen Science, eds. D. Cavalier and E. B. Kennedy. Tempe, AZ: Consortium for Science, Policy, and Outcomes, 89-103.

31. Pant, L. P. 2019. 'Responsible Innovation Through Conscious Contestation at the Interface of Agricultural Science, Policy, and Civil Society', Agriculture and Human Values 36(2): 183-197.

32. Pecl, G. T.; Stuart-Smith, J.; Walsh, P.; Bray, D.; Brians, M.; Burgess, M.; Keane, J. 2019. 'Redmap Australia: Challenges and Successes with a Large-scale Citizen Science-based Approach to Ecological Monitoring and Community Engagement on Climate Change', Frontiers in Marine Science 6: 349.

33. Pescott, O. L.; Walker, K. J.; Harris, F.; New, H.; Cheffings, C. M.; Newton, N.; Roy, D. B. 2019. 'The Design, Launch and Assessment of a New Volunteer-based Plant Monitoring Scheme for the United Kingdom', PloS One 14(4): e0215891.

34. Pohl, C.; Hirsch Hadorn, G. 2008. 'Methodological Challenges for Transdisciplinary Research', Natures Sciences Sociétés 16: 111-121.

35. Prahalad, C. K.; Ramaswamy, V. 2004. 'Co-creation Experiences: The Next Practice in Value Creation', Journal of Interactive Marketing 18: 5-14.

36. Purdam, K. 2014. 'Citizen Social Science and Citizen Data? Methodological and Ethical Challenges for Social Research', Current Sociology 62(3): 374-392.

37. Rogers, A.; Rock, J. 2017. 'Testing a Mobile Platform for Community Co-created Exhibitions', Curator: The Museum Journal 60(3): 335-349.

38. Rushmer, R.; Ward, V.; Nguyen, T.; Kuchenmüller, T. 2019. 'Knowledge Translation: Key Concepts, Terms and Activities', in Population Health Monitoring. Cham: Springer, 127-150.

39. Schröter, M.; Kraemer, R.; Mantel, M.; Kabisch, N.; Hecker, S.; Richter, A.; Bonn, A. 2017. 'Citizen Science for Assessing Ecosystem Services: Status, Challenges and Opportunities', Ecosystem Services 28: 80-94.

40. Suess-Reyes, J.; Hyslop, K.; Beck, S.; Poetz, M. K.; Krasnikov, T.; Prinsloo, A. 2020. 'May the Force Be with Them: Exploring Strategies to Overcome Challenges of Co-created Citizen Science', in Academy of Management Proceedings. Vol. 2020. No. 1. Briarcliff Manor, NY: Academy of Management.

41. Tauginiene, L.; Butkevičienè, E.; Vohland, K.; Heinisch, B.; Daskolia, M.; Suškevičs, M.; Portela, M.; Balázs, B.; Prūse, B. 2020. 'Citizen Science in the Social Sciences and Humanities: The Power of Interdisciplinarity', Palgrave Communications 6(89). Available at: https://doi.org/10.1057/s41599-0200471-y

42. Tiago, P.; Gouveia, M. J.; Capinha, C.; Santos-Reis, M.; Pereira, H. M. 2017. 'The Influence of Motivational Factors on the Frequency of Participation in Citizen Science Activities', Nature Conservation 18: 61-78. Available at: https://doi.org/10.3897/natureconservation.18.13429 
43. Torras-Gómez, E.; Guo, M.; Ramis, M. 2019. 'Sociological Theory from Dialogic Democracy', International and Multidisciplinary Journal of Social Sciences 8(3): 216-234.

44. Wang, W.; Bryan-Kinns, N.; Ji, T. 2016. 'Using Community Engagement to Drive Co-creation in Rural China', International Journal of Design 10(1): 37-52.

MONIKA MAČIULIENĖ, EGLĖ BUTKEVIČIENĖ, EGLE் VAIDELYTĖ, BÁLINT BALÁZS

\title{
Socialinių pokyčių visuomenèje bendrakūra pasitelkiant piliečių mokslą: sisteminẻ literatūros analizè
}

\begin{abstract}
Santrauka
Mokslininkų ir visuomenès narių bendrakūra kuriant socialinius pokyčius ir sprendžiant socialines problemas vyksta visame pasaulyje. Mokslo bendruomenès nariai ir piliečiai pradeda eksperimentuoti naudodami skaitmeninius ir neskaitmeninius išteklius. Visuomenès nariai, įsitraukdami ị piliečių mokslą, sugeba rasti būdų, kaip padaryti mokslą naudingą sau, savo bendruomenèms, darbo aplinkai ir visuomenei. Suinteresuotų šalių dalyvavimas demokratizuoja mokslą ir padidina tyrejų atsakomybę prieš visuomenę. Šiame straipsnyje siekiama aptarti galimą piliečiu mokslo vaidmenį kuriant socialinius pokyčius visuomeneje ar vietos bendruomenejje. Straipsnis pagrịstas sistemine literatūros analize. Išvados rodo, kad piliečių ir mokslininkų bendrakūra pasitelkiant piliečių mokslą gali ypač stipriai paveikti visuomenès gerovę ir vietos ar regiono bendruomenę. Tačiau tokie atvejai dar nèra labai dažni. Nors tyrimai, susiję su piliečiu mokslu ir suinteresuotųjų šalių ịsitraukimu ị bendrakūros procesus, nuolat auga, jie vis dar išlieka gana nauja sritimi.
\end{abstract}

Raktažodžiai: piliečių mokslas, socialiniai pokyčiai, bendrakūra, sisteminè literatūros apžvalga 